7 Smart IJ, Koh LY. Competitive inhibition enzyme immunoassays for the measurement of human IgG, IgA, and IgM. F Immunol Methods 1983;60 329-39.

8 Lowry OH, Rosebrough NJ, Farr AL, Randall RJ. Protein measurement with the folin phenol reagent. I Biol Chem 1951;193:265-75.

9 Forsyth $\mathrm{KD}$, Koh L, Lawrence A, Bradley J. Immunoglobulin profile of tracheal aspirate fluid in intubated children. Clin Exp Immunol 1988;71: $357-61$

10 Ogra PL, Ogra SS, Coppola PR. Secretory component and sudden infant death syndrome. Lancet 1975; ii: 387-90.

11 Ackermann WW, Eveland WC, Maverakis NH, Raven C, Golden A. Bound immunoglobulin and foreign antigen in lungs of sudden infant death syndrome victims. Infect Immun 1979;24:925-31.

12 Raven C, Maverakis NH, Eveland WC, Ackermann Ww. The sudden infan death syndrome: a possible hypersensitivity reaction determined by distribution of IgG in lungs. F Forensic Sci 1978;23:116-28.

13 Valdes-Dapena MA. Sudden infant death syndrome: a review of the medical literature. Pediatrics 1980;66:597-614.

14 Coombs RRA, McLaughlan P. The enigma of cot death: is the modified anaphylaxis hypothesis an explanation for some cases? Lancet 1982;i:1388-9.

(Accepted 4 November 1988)

\title{
Serious eye injuries due to war games
}

\section{J F Acheson, M F P Griffiths, R J Cooling}

Accident and Emergency Department and Primary Care Clinic, Moorfields Eye Hospital, London EC1 2PD

J F Acheson, FRCS, registrar in ophthalmology

M F P Griffiths, FRCs, locum senior registrar in

ophthalmology

R J Cooling, FRCS, consultant ophthalmic surgeon

Correspondence to: $\mathrm{Mr} \mathrm{J} \mathrm{F}$

Acheson, Western

Ophthalmic Hospital,

London NW1.

Br.Med f 1989;298:26.
"War games" are an outdoor activity combining recreation, military style manoeuvres, and fantasy. Combatants in the games fire gelatin pellets filled with dye at each other from powerful air guns. War games' weaponry developed from paint guns used by forestry workers to mark trees for felling. These guns are powered either by carbon dioxide cartridges or by rounds detonated by percussion. Gas cartridge weapons are not classified as firearms in the United Kingdom, in contrast to rounds detonated by percussion. The ammunition comprises pellets filled with paint, and the guns are remarkably realistic, resembling revolvers, semiautomatic handguns, rifles, or machine pistols. Muzzle velocities of up to $134 \mathrm{~m} / \mathrm{s}$ and energies of $10 \mathrm{~J}$ are possible with rates of fire of 1200 rounds a minute. Combatants are issued with protective goggles, and shots aimed at the head are prohibited.

\section{Case reports}

Although goggles should be worn and the head avoided, during July 1987 to February 1988 we saw six cases of serious ocular injury resulting from war games. The table summarises these cases.

\section{Comment}

Serious injuries due to war games were first reported in Canada in 1984..$^{23}$ To our knowledge they have not been reported in Britain, presumably because this new pastime is not yet so popular in this country. Easterbrook et al reviewed data collected by the eye safety committee of the Canadian Society of Ophthalmology and described 26 cases, including one of a ruptured eve, which was eventually excised. ${ }^{2}$ They noted that though eyeguards had been provided in all instances, none were in use at the time of injury. Subsequently two isolated cases were reported from the United States $^{+\varsigma}$; in one goggles were being worn but did not prevent hyphaema, vitreous haemorrhage, and a retinal tear. ${ }^{5}$

Goggles were supplied to all our six patients; a lens from one pair, however, dropped out spontaneously, and in three cases the goggles were removed for extra comfort and visibility before injury. In the remaining two patients who were wearing goggles both injuries resulted from the plastic pellet dislocating the lens from the frame and driving it on to the eye. The toughened protective glasses and rubber rimmed industrial goggles were inadequate, and single piece polycarbonate eye protectors such as those recommended for racket sports seem more suitable.

The injuries reported were of a blunt, non-penetrating type normally associated with fairly low kinetic energies further dissipated by goggles, when worn. Permanent visual loss, however, may result from these games as the weapons have sufficient muzzle velocities to cause penetration of the eye. Moreover, though the retained subconjunctival dye in case 4 did not seem to be toxic, blunt ocular injury carries considerable morbidity. Emergency admission to hospital was required in three of our six cases to treat raised intraocular pressure and to minimise the risk of rebleeding hyphaema. All six patients required prolonged follow up to identify and treat delayed complications such as secondary glaucoma, contusion cataract, recurrent corneal erosion syndrome, retinal pigment epithelial degeneration, and retinal detachment.

We gratefully acknowledge the help of Mr D Pryor, Metropolitan police laboratory, firearms section

1 Warner K, ed. Gun digest catalogue. 42nd ed. Illinois: BBI Books Inc, 1988: 416-7.

2 Easterbrook M, Pashby TJ. Eye injuries associated with war games. Can Med Assoc f 1985;133:415-7.

3 Tardif D, Little J, Mercier M, Podtenenev M, Labelle P. Ocular trauma in war games. Physician and Sports Medicine 1986; 14:91-4.

games. Physician and Sports Medicine 1986;14:91-4.
4 Ryan EH, Lissner G. Eye injuries during "war games." Arch Ophthalmol 1986; 104:1435-6.

5 Martin PL, Magolan JJ. Eye injury during "war games" despite the use of goggles; case report. Arch Ophthalmol 1987;105:321-2.

(Accepted 26 September 1988

Details of six cases of ocular injury due to weapons used in war games

\begin{tabular}{|c|c|c|c|c|c|c|}
\hline $\begin{array}{l}\text { Case } \\
\text { No }\end{array}$ & $\begin{array}{c}\text { Age } \\
\text { (years) }\end{array}$ & $\begin{array}{l}\text { Wearing } \\
\text { goggles }\end{array}$ & $\begin{array}{l}\text { Emergency } \\
\text { admission } \\
\text { to hospital }\end{array}$ & $\begin{array}{l}\text { Initial } \\
\text { visual } \\
\text { acuity }\end{array}$ & Presentation & $\begin{array}{l}\text { Final visual acuity } \\
\text { (months later) }\end{array}$ \\
\hline 1 & 16 & No & Yes & $\begin{array}{c}\text { Hand } \\
\text { movements }\end{array}$ & $\begin{array}{l}\text { Corneal abrasion, hyphaema, contusion cataract, } \\
\text { contusion of retina, and subsequent atrophy of } \\
\text { retinal pigment epithelium }\end{array}$ & $\begin{array}{l}6 / 12 \text { (Six months; after } \\
\text { extraction of cataract and } \\
\text { insertion of aphakic contact } \\
\text { lens) }\end{array}$ \\
\hline 2 & 35 & Yes & Yes & $6 / 12$ & $\begin{array}{l}\text { Conjunctival laceration, hyphaema, drainage angle } \\
\text { recession, rupture of iris sphincter, and contusion } \\
\text { of retina }\end{array}$ & \\
\hline 3 & 28 & Yes & No & $6 / 6$ & Hyphaema, corneal abrasion & 6/6 (Two months) \\
\hline 4 & 38 & No & Yes & $6 / 24$ & $\begin{array}{l}\text { Conjunctival laceration, retained subconjunctival } \\
\text { vegetable dye, corneal abrasion, hyphaema, } \\
\text { rupture of iris sphincter, vitreous haemorrhage, } \\
\text { contusion of retina, atrophy of retinal pigment } \\
\text { epithelium }\end{array}$ & $6 / 12$ (Three months) \\
\hline 5 & 24 & No & No & $6 / 5$ & $\begin{array}{l}\text { Hyphaema, transient raised intraocular pressure, } \\
\text { vitreous haemorrhage, retinal tear (treated by } \\
\text { cryopexy) }\end{array}$ & $6 / 6$ (Three months) \\
\hline 6 & 19 & No & No & $6 / 5$ & Hyphaema, drainage angle recession & $6 / 5$ (One month) \\
\hline
\end{tabular}

